University of Nebraska - Lincoln

DigitalCommons@University of Nebraska - Lincoln

Agronomy \& Horticulture -- Faculty Publications

Agronomy and Horticulture Department

7-1982

\title{
Variability for Quality and Agronomic Traits in Forage Sorghum Hybrids
}

\author{
J. F. Pedersen \\ Auburn University, jpedersen1@unl.edu \\ Herman J. Gorz \\ United States Department of Agriculture \\ Francis A. Haskins \\ University of Nebraska-Lincoln, fhaskins@neb.rr.com \\ W. M. Ross \\ United States Department of Agriculture
}

Follow this and additional works at: https://digitalcommons.unl.edu/agronomyfacpub

Part of the Plant Sciences Commons

Pedersen, J. F.; Gorz, Herman J.; Haskins, Francis A.; and Ross, W. M., "Variability for Quality and Agronomic Traits in Forage Sorghum Hybrids" (1982). Agronomy \& Horticulture -- Faculty Publications. 229.

https://digitalcommons.unl.edu/agronomyfacpub/229

This Article is brought to you for free and open access by the Agronomy and Horticulture Department at DigitalCommons@University of Nebraska - Lincoln. It has been accepted for inclusion in Agronomy \& Horticulture -Faculty Publications by an authorized administrator of DigitalCommons@University of Nebraska - Lincoln. 


\title{
Variability for Quality and Agronomic Traits in Forage Sorghum Hybrids $^{1}$
}

\author{
J. F. Pedersen, H. J. Gorz, F. A. Haskins, and W. M. Ross ${ }^{2}$
}

\begin{abstract}
The variation among $49 F_{1}$ forage sorghum [Sorghum bicolor $(L$. Moench] hybrids from a $7 \times 7$ cross-classified design was explored in 1979 and 1980 for the following traits: dry matter (DM), crude protein (CP), in vitro dry matter disappearance (IVDMD), neutral detergent fiber (NDF), acid detergent fiber (ADF), and acid detergent lignin (ADL). Differences were found among hybrids for all traits. Parental means for males generally had a wider range of variation than for females. The means of hybrids involving the male parent, 'White Collier', were highest in IVDMD, and lowest in NDF, ADF, and ADL.

IVDMD was the only trait that showed significant differences among hybrids averaged over both males and females. General combining ability (GCA) effects were more important than specific combining ability effects.

Our results suggest that the most rapid way to improve forage sorghum quality would be by improving IVDMD. Significant differences among hybrids averaged over both male and female parents were shown for this trait; it was affected relatively little by year effects and exhibited high GCA effects.
\end{abstract}

Additional index words: Sorghum bicolor (L.) Moench, Heritability, Combining ability, Digestibility, Protein, Fiber, Lignin.

$\mathrm{N}$ the United States, sorghum [Sorghum bicolor (L.) Moench] grown for silage or forage occupies an acreage less than one-tenth that of corn (Zea mays L.) planted for the same purposes (19). This large difference in acreage may be due, in part, to reports that indicate a lower feeding value for forage sorghum silage than for corn silage (15). The reasons for this lower feed value are not fully understood, but they probably involve relatively low intake, digestibility, and dry matter content, and relatively high cell wall content $(5,15)$. Until the feeding value of forage sorghum can be improved, it will probably continue to be grown as now, primarily on land that is marginally or poorly suited for growing corn because of limited rainfall or frequent periods of drought $(11,12)$.

Knowledge about the inheritance of specific quality traits in forage sorghum is needed to permit the optimal development of breeding strategies for improving those traits. However, progress in inheritance studies is

'Joint contribution of the USDA-ARS and the Nebraska Agric. Exp. Stn., Lincoln. Published as Paper No. 6678, Journal Series, Nebraska Agric. Exp. Stn. The work reported was conducted under Nebraska Agric. Exp. Stn. Projects 12-088 and 12-114. Received 29 Oct. 1981.

${ }^{2}$ Formerly graduate research assistant (now assistant professor of agronomy, Auburn Univ., Auburn, AL 36849); supervisory research geneticist, USDA-ARS; George Holmes professor of agronomy, Univ. of Nebraska; and research geneticist, USDA-ARS, Lincoln, NE 68583 , respectively. 
dependent upon the availability of reasonably precise but relatively simple laboratory procedures for measuring the levels of quality traits in large plant populations. Fortunately, several procedures have been developed that can be used effectively in genetic and breeding studies. Crude protein (CP) is easily measured by the Kjeldahl procedure (10), and digestibility can be estimated accurately as in vitro dry matter disappearance (IVDMD)with the twostage technique described by Tilley and Terry (18). The detergent fractionation procedure described by Goering and Van Soest (7) involves the breakdown of forage material into cell solubles, neutral detergent fiber (NDF), acid detergent fiber (ADF), acid detergent lignin (ADL), and ash. These fractions have been shown to be related in various ways to digestibility and intake. The ADF and $\mathrm{ADL}$ fractions frequently are related to digestibility with the amount of lignin often limiting the extent of digestion. Intake cannot be measured easily and accurately in the laboratory, but it appears to be most strongly associated with the cell wall fraction as measured by $\operatorname{NDF}(20,21$, 22). Ward et al. (24) also have shown that percent dry matter (DM) of forage sorghum silage is highly correlated with DM intake.

Although many studies involving combining ability and heritability in grain sorghum have been done, few have been published on forage sorghum. Most forage sorghum combining ability studies have dealt with yield and its components $(1,3,8,9,14,17)$. Published reports concerning the inheritance of quality traits in forage sorghum appear to be limited to CP and IVDMD $(4,9,14)$. No information concerning the inheritance of NDF, ADF, $\mathrm{ADL}$, or ash was found. For most traits that have been studied in forage sorghum, general combining ability (GCA) was of greater importance than specific combining ability (SCA). However, SCA appeared to be of greater importance than GCA for CP $(4,14)$.

The objectives of this study were to determine the extent of variation for yield and several quality traits in a group of 49 experimental forage sorghum hybrids and to estimate the relative proportion of the variation that was caused by genetic effects. In addition, the relative magnitude of GCA and SCA effects, as well as the relative contributions of the male and female parents to the GCA effects, were estimated.

\section{MATERIALS AND METHODS}

Seven male-sterile lines ('Redlan', 'N35', 'N38', 'N48', 'N4692', 'KS5', 'N5013'3) were each crossed to seven males 'Early Hegari-Sart' (EH-Sart) $)^{3}$ 'Early Hegari-White Sourless' (EH-WS) $)^{3}$ 'Early Hegari-Rox' (EH-Rox)', 'N6229', 'Rox', 'White Collier' (WC), and 'H60-29's to produce $49 \mathrm{~F}_{1}$ hybrids.

The 49 hybrids were grown in 1979 and 1980 in a randomized complete block design with three replications at the Univ. of Nebraska Field Laboratory, Mead. Plots consisted of three 9.14$\mathrm{m}$ rows spaced $0.76 \mathrm{~m}$ apart with plants hand-thinned to a spacing of approximately $15 \mathrm{~cm}$. An application of $112 \mathrm{~kg} \mathrm{~N} / \mathrm{ha}$ was disked in prior to planting on 24 May 1979 and 29 May 1980. Severe damage to the emerging seedlings by black cutworms (Agrotis ipsilon Hufnagel) in 1980 necessitated treatment of the plot area with an insecticide, followed by replanting on 12 June

${ }^{3}$ Experimental forage sorghum lines. without additional land preparation. Immediately following planting, a mixture of propachlor (2-chloro- $N$-isopropyl-acetanilide) + atrazine [2-chloro-4-(ethylamino)-6-(isopropylamino)-s-triazine] at $3.75+1.25 \mathrm{~kg}$ a.i./ha was applied for weed control. Approximately $2.5 \mathrm{~cm}$ of water was applied with sprinklers from 6 June to 8 June 1979 , and about $10.2 \mathrm{~cm}$ was applied similarly on 25 July 1980 due to extremely dry conditions.

Plots were harvested from 24 to 27 Sept. 1979 and on 6 and 7 Oct. 1980 . In 1980, a killing frost occurred 4 days prior to harvest. A $4.75-\mathrm{m}$ section of the middle row of each plot was harvested and weighed to determine total plot yield. Heads were then cut from the stalks and weighed, and a random subsample was dried to constant weight at $60 \mathrm{C}$ for dry matter determination. Five random stalks and five random heads were composited, passed through a small chopper, mixed thoroughly, and sampled for dry matter determination and laboratory analyses. Samples were dried to constant weight in a forced air oven at 60 $\mathrm{C}$, ground in a Wiley ${ }^{4}$ mill to pass a $1-\mathrm{mm}$ screen and stored at room temperature in $32-\mathrm{ml}$ vials.

The following traits were measured:

$\% D M$. Calculated from the difference in weights of fresh samples and samples dried at $60 \mathrm{C}$ to constant weight.

$\% C P(\% N \times 6.25))$. Determined by the Kjeldahl procedure $(10)$.

IVDMD. Determined by the two-stage technique of Tilley and Terry (18) and expressed as a percentage.

$\% N D F$. Determined by the high concentrate procedure of Robertson and Van Soest (13).

$\% A D F, A D L$. Determined by the detergent fractionation procedures of Goering and Van Soest (7).

Head Yield and Total Yield. Expressed in metric tons DM/ha.

Analyses of variance and genetic analyses followed the method described by Ross et al. (14). Pertinent information from their description is repeated here. For the genetic analyses, the entry source of variation was partitioned into females, males, and females $\times$ males, and the entry $\times$ year interactions were partitioned into females $x$ years, males $\times$ years, and females $\times$ males $x$ years. Mean squares (MS) were equated to their expected values and solved for components estimating the variance among the fixed effects in the corresponding sources of variation. F-tests were made for females as $\mathrm{MS}_{\mathrm{f}} / \mathrm{MS}_{\mathrm{ty}}$, for males as $\mathrm{MS}_{\mathrm{m}} / \mathrm{MS}_{\mathrm{rix}}$, for females $\times$ males as $\mathrm{MS}_{\mathrm{lim}} / \mathrm{MS}_{\text {limy }}$, and for females $\times$ males $\times$ years as $\mathrm{MS}_{\mathrm{im}} / \mathrm{MS}_{\mathrm{e}}$.

Genetic ratios were estimated as follows:

$$
\begin{aligned}
& \frac{\theta_{\mathrm{f}}^{2}}{\sigma_{\mathrm{e}}^{2} / \mathrm{RMY}+\sigma_{\mathrm{fmy}}^{2} / \mathrm{MY}+\theta_{\mathrm{fm}}^{2} / \mathrm{M}+\sigma_{\mathrm{fy}}^{2} / \mathrm{Y}+\theta_{\mathrm{f}}^{2}}=\frac{\theta_{\mathrm{f}}^{2}}{\theta_{\mathrm{P}_{\mathrm{f}}}^{2}}, \\
& \frac{\theta_{\mathrm{m}}^{2}}{\sigma_{\mathrm{e}}^{2} / \mathrm{RFY}+\sigma_{\mathrm{fmy}}^{2} / \mathrm{FY}+\theta_{\mathrm{fm}}^{2} / \mathrm{F}+\sigma_{\mathrm{my}}^{2} / \mathrm{Y}+\theta_{\mathrm{m}}^{2}}=\frac{\theta_{\mathrm{m}}^{2}}{\theta_{\mathrm{P}_{\mathrm{m}}}^{2}} \text {, and } \\
& \frac{\theta_{\mathrm{fm}}^{2}}{\sigma_{\mathrm{e}}^{2} / \mathrm{RY}+\sigma_{\mathrm{fmy}}^{2} / \mathrm{Y}+\theta_{\mathrm{fm}}^{2}}=\frac{\theta_{\mathrm{fm}}^{2}}{\theta_{\mathrm{P}_{\mathrm{fm}}}^{2}}, \text { where the symbol }
\end{aligned}
$$

$\theta^{2}$ indicates fixed effects and $\sigma^{2}$ indicates random effects.

The ratio $\theta^{2} d \theta^{2}$ estimates GCA based on females, $\theta^{2}{ }_{\mathrm{rm}} / \theta^{2}{ }_{\mathrm{P}_{\mathrm{m}}}$ estimates GCA based on males, and $\theta_{{ }_{\mathrm{fm}}} / \theta_{\mathrm{p}_{\mathrm{t}} \mathrm{rm}}$ estimates SCA based on females $\times$ males. The symbols $\theta^{2}, \theta^{2}{ }_{m}^{2}, \theta^{2}{ }_{\text {ly }}, \sigma^{2}{ }_{m y}, \theta^{2}{ }_{\text {lim }}$, $\sigma_{\text {imy }}$, and $\sigma^{2}$, are the components for females, males, females $\times$ years, males $x$ years, females $x$ males, females $\times$ males $\times$ years, and error, respectively; the symbol $\theta^{2}{ }_{\mathrm{p}}$ with the appropriate subscript is analogous to an estimate of phenotypic variance. The symbols $\mathrm{F}, \mathrm{M}, \mathrm{Y}$, and $\mathrm{R}$ in the denominator indicate the

${ }^{4}$ Mention of a trademark, proprietary product, or vendor does not constitute a guarantee or warranty of the USDA or the Univ. of Nebraska and does not imply its approval to the exclusion of other products or vendors that may also be suitable. 
Table 1. Means of quality and agronomic traits of $49 F_{1}$ forage sorghum hybrids grown at Mead, Nebr. in 1979-1980.

\begin{tabular}{|c|c|c|c|c|c|c|c|c|}
\hline \multirow[b]{3}{*}{ Group } & \multicolumn{8}{|c|}{ Trait } \\
\hline & \multirow[b]{2}{*}{ DM } & \multirow[b]{2}{*}{ CP } & \multirow[b]{2}{*}{ IVDMD } & \multirow[b]{2}{*}{$\mathrm{NDF}$} & \multirow[b]{2}{*}{ ADF } & \multirow[b]{2}{*}{ ADL } & \multicolumn{2}{|c|}{ DM yield } \\
\hline & & & & & & & Head & Total \\
\hline & & & $\%$ & & & & metric & tons/h \\
\hline \multicolumn{9}{|l|}{ Male mean } \\
\hline$\overline{\text { EH-Sart }}$ & 29.0 & 5.5 & 52.3 & 55.5 & 32.3 & 5.1 & 5.3 & 20.1 \\
\hline EH-WS & 33.6 & 6.2 & 53.2 & 52.6 & 31.0 & 5.6 & 7.1 & 16.8 \\
\hline EH-Rox & 34.5 & 6.0 & 54.6 & 51.8 & 30.0 & 5.1 & 7.1 & 17.4 \\
\hline N6229 & 29.1 & 5.6 & 52.4 & 56.6 & 34.1 & 5.5 & 6.0 & 19.8 \\
\hline H60-29 & 33.6 & 6.8 & 55.1 & 51.3 & 29.5 & 5.0 & 6.0 & 16.0 \\
\hline Rox & 30.2 & 6.3 & 55.3 & 52.2 & 30.5 & 5.0 & 6.1 & 16.7 \\
\hline WC & 32.5 & 5.9 & 58.0 & 50.2 & 28.2 & 4.4 & 5.5 & 17.9 \\
\hline L.S.D. (0.05) & 3.3 & NS & 2.1 & 2.8 & NS & NS & NS & NS \\
\hline \multicolumn{9}{|l|}{ Female mean } \\
\hline N5013 & 30.4 & 6.0 & 53.6 & 53.7 & 31.5 & 5.2 & 5.2 & 17.5 \\
\hline N48 & 31.3 & 5.8 & 55.0 & 52.2 & 30.3 & 4.8 & 6.1 & 18.7 \\
\hline N4692 & 30.1 & 5.9 & 53.8 & 54.8 & 32.4 & 5.4 & 6.0 & 18.1 \\
\hline KS5 & 32.3 & 6.2 & 56.1 & 50.5 & 29.3 & 4.9 & 6.3 & 18.1 \\
\hline N38 & 33.3 & 6.1 & 53.9 & 53.3 & 30.4 & 5.0 & 6.3 & 18.6 \\
\hline N35 & 32.4 & 6.3 & 54.7 & 52.3 & 30.3 & 5.3 & 6.8 & 17.2 \\
\hline Redlan & 32.8 & 6.2 & 53.6 & 53.4 & 31.2 & 5.1 & 6.4 & 16.4 \\
\hline L.S.D. $(0.05)$ & NS & NS & 0.9 & NS & NS & NS & 0.7 & 1.4 \\
\hline \multicolumn{9}{|l|}{$\begin{array}{l}\text { Overall mean } \\
\text { and range }\end{array}$} \\
\hline Mean & 31.8 & 6.1 & 54.4 & 52.9 & 30.8 & 5.1 & 6.2 & 17.8 \\
\hline Maximum & 38.9 & 7.3 & 60.0 & 59.0 & 37.3 & 6.6 & 8.3 & 22.9 \\
\hline Minimum & 26.2 & 5.0 & 49.1 & 47.6 & 27.0 & 3.9 & 4.2 & 13.0 \\
\hline
\end{tabular}

number of observations on females, males, years, and replications, respectively. The above symbol designations for components are similar to those of Snedecor and Cochran (16) who used $\mathbf{k}$ instead of $\theta$ for fixed effects.

As pointed out by Ross et al. (14), statistical treatment of fixed lines to draw inferences about hypothetical populations, is not entirely appropriate. However, with qualifications, quantitative genetic information can be drawn from such studies that may aid in the improvement of quality and yield of forage sorghum.

\section{RESULTS AND DISGUSSION}

Significant differences among individual hybrid means were found for all traits. Presentation of all means is not feasible because of the large number of hybrids and traits involved. Therefore, only parental group means and overall means and ranges are shown (Table 1). Several general trends are evident. Parental means for males usually had a wider range than those for females, probably because of inherent differences in the male and female parental germplasm used in these experiments. A comparison of parental means for various traits revealed relationships that characterized the apparent high or low quality of specific parents. For example, the means of hybrids involving the male parent, WC, were highest in IVDMD and lowest in NDF, ADF, and ADL. Thus the high IVDMD of WC hybrids was apparently due, at least in part, to a high percentage of cell solubles $(100 \%$ $\%$ NDF), and a low lignin content. On the other hand, the means of hybrids involving EH-Sart and N6229 as male parents were comparatively low in IVDMD and CP and high in NDF, ADF, and ADL. The low CP contents in these hybrids may be below the level required for optimal microbial action in the rumen fluid used in the IVDMD procedure and, therefore, may also contribute to the low IVDMD values observed.
Performance of individual hybrids provided information of interest to sorghum breeders. For example, one hybrid, N4692 $\times$ EH-Sart, was among the four top-yielding entries in both years. Most of the hybrids with the highest IVDMD values included the male parent, WC, as expected from the information presented on parental means. Four hybrids, N4692 $\times$ WC, KS $\times$ WC, N38 $\times W C$, and $\mathrm{N} 35 \times \mathrm{WC}$ were among the best entries, in terms of IVDMD, in both years. Hybrids combining superior yield and IVDMD were not the same in both years, but N4692 $\times$ WC had high IVDMD in both years, and high yield in 1979 . Thus, N4692 probably contributes to high yield and WC to improved IVDMD. These parents appear to merit further consideration in forage sorghum breeding programs.

Mean squares are shown in Table 2. Although a valid test of significance for the year $(\mathrm{Y})$ mean squares cannot be made, it is apparent that these values are much greater than any of the other mean squares for all traits except $\mathrm{DM}$. The $\mathrm{F} \times \mathrm{Y}$ interaction was significant for $\mathrm{DM}$, and $M \times Y$ interactions were significant for all traits except IVDMD. The $\mathrm{F} \times \mathrm{M} \times \mathrm{Y}$ interactions were significant for DM and NDF.

The only traits for which significant differences were found among hybrid means for males, females, or for the $\mathrm{F} \times \mathrm{M}$ interaction were IVDMD for both males and females, DM and NDF for males, head yield and total yield for females, and ADF and head yield for the $F \times M$ interaction. The large number of nonsignificant findings for female and male traits are attributable to the magnitudes of the year interaction mean squares used in the denominators of the F-test. The significant differences in IVDMD for hybrids averaged over both males and females, plus the lack of any significant interactions with years, indicated that IVDMD was the most useful trait for the improvement of forage quality by breeding among those included in this study.

Genotypic components and genetic ratios for these traits are presented in Table 3 . Values of $\theta^{2}$ were generally higher than for $\theta_{\mathrm{f}}^{2}$ or $\theta_{\mathrm{f}_{\mathrm{fr}}}^{2}$. High $\theta_{\mathrm{f}}^{2} / \theta_{\mathrm{pf}}{ }_{\mathrm{p}}$ and $\theta_{\mathrm{m}}^{2} / \theta_{\mathrm{p}_{\mathrm{m}}}^{2}$ values indicated that GCA effects were of more importance than SCA effects for these traits.

Simple correlation coefficients between various pairs of traits revealed many statistically significant values, but many values were so low as to be of little predictive importance. Some of the highest values were the negative relationships of IVDMD with NDF (-0.58), ADF $(-0.50)$, and ADL $(-0.45)$. These correlations support the relationships described above for hybrid means averaged over the male parents, WC, EH-Sart, and N6229. Relatively high correlation coefficients were observed between NDF and $\mathrm{ADF}(0.79)$ and ADF and ADL (0.72). Correlation coefficients of similar magnitude were calculated for these two relationships from data previously presented by Van Soest and Moore (23). These high values are not surprising in view of the sequential procedures for determining NDF, $\mathrm{ADF}$, and ADL.

Data obtained in these studies show the feasibility of improving quality traits in forage sorghum by breeding. For several quality traits GCA was most important. Progress would be optimized by emphasizing the improve- 
Table 2. Analyses of variance for quality and agronomic traits in $49 \mathrm{~F}_{1}$ forage sorghum hybrids grown at Mead, Nebr. in $1979-1980$.

\begin{tabular}{|c|c|c|c|c|c|c|c|c|c|}
\hline \multirow[b]{3}{*}{ Source } & \multirow[b]{3}{*}{ df } & \multicolumn{8}{|c|}{ Trait mean square } \\
\hline & & \multirow[b]{2}{*}{ DM } & \multirow[b]{2}{*}{$\mathrm{CP}$} & \multirow[b]{2}{*}{ IVDMD } & \multirow[b]{2}{*}{ NDF } & \multirow[b]{2}{*}{ ADF } & \multirow[b]{2}{*}{ ADL } & \multicolumn{2}{|c|}{ DM yield } \\
\hline & & & & & & & & Head & Total \\
\hline Year (Y) & 1 & 7.6 & 63.75 & $1,162.3$ & 604.8 & 326.3 & 113.7 & 546.8 & $1,668.5$ \\
\hline Female (F) & 6 & 64.1 & 1.43 & $35.4^{*}$ & 80.5 & 43.3 & 1.7 & $10.3^{*}$ & $29.0^{*}$ \\
\hline Male (M) & 6 & $221.4^{*}$ & 7.60 & $168.5^{*}$ & $224.1^{*}$ & 156.0 & 6.2 & 21.6 & 106.4 \\
\hline $\mathbf{F} \times \mathbf{M}$ & 36 & 16.8 & 0.65 & 15.5 & 16.0 & $17.2^{*}$ & 1.2 & $1.6^{*}$ & 9.8 \\
\hline $\mathbf{F} \times \mathbf{Y}$ & 6 & $21.3^{*}$ & 0.64 & 3.1 & 22.3 & 23.3 & 1.7 & 1.8 & 6.9 \\
\hline $\mathbf{M} \times \mathbf{Y}$ & 6 & $38.2^{*}$ & $5.13^{*}$ & 15.7 & $28.3^{*}$ & $49.7^{*}$ & $2.8^{*}$ & $17.4^{*}$ & $35.2^{*}$ \\
\hline $\mathbf{F} \times \mathbf{M} \times \mathbf{Y}$ & 36 & $15.5^{*}$ & 0.58 & 10.5 & $21.7 *$ & 9.9 & 1.1 & 0.8 & 14.0 \\
\hline Error & 192 & 9.9 & 0.59 & 11.6 & 12.7 & 12.4 & 1.1 & 1.0 & 10.4 \\
\hline
\end{tabular}

* Significant at the 0.05 probability level.

Table 3. Quantitative genetic estimates of quality traits in $49 \mathrm{~F}_{1}$ forage sorghum hybrids grown at Mead, Nebr. in 1979-1980.

\begin{tabular}{|c|c|c|c|c|c|c|}
\hline \multirow[b]{3}{*}{ Trait } & \multicolumn{6}{|c|}{ Parameter estimated $\dagger$} \\
\hline & \multicolumn{3}{|c|}{ Genotypic component } & \multicolumn{3}{|c|}{ Genetic ratio } \\
\hline & $\theta_{\mathrm{f}}^{2}$ & $\theta_{\mathrm{m}}^{2}$ & $\theta_{\mathrm{fm}}^{2}$ & $\theta_{\mathrm{f}}^{z} / \theta_{\mathrm{P}_{\mathrm{f}}}^{z}$ & $\theta_{\mathrm{m}}^{2} / \theta_{\mathrm{P}}^{2}$ & $\theta_{\mathrm{fm}}^{2} / \theta_{\mathrm{P}_{\mathrm{fm}}}^{2}$ \\
\hline DM & 0.99 & 4.33 & 0.22 & 0.65 & 0.82 & 0.08 \\
\hline $\mathrm{CP}$ & 0.02 & 0.06 & 0.01 & 0.51 & 0.32 & 0.10 \\
\hline IVDMD & 0.65 & 3.52 & 0.83 & 0.77 & 0.88 & 0.32 \\
\hline NDF & 1.52 & 4.80 & 0.00 & 0.79 & 0.90 & 0.00 \\
\hline ADF & 0.30 & 2.36 & 1.21 & 0.29 & 0.64 & 0.42 \\
\hline ADL & 0.00 & 0.08 & 0.03 & 0.00 & 0.53 & 0.12 \\
\hline Head yield & 0.18 & 0.08 & 0.13 & 0.75 & 0.16 & 0.49 \\
\hline Total yield & 0.63 & 1.79 & 0.00 & 0.91 & 0.71 & 0.00 \\
\hline
\end{tabular}

$\dagger \theta_{\mathrm{f}}^{2}, \theta_{\mathrm{m}}^{2}$, and $\theta_{\mathrm{fm}}^{2}$ are the variances for females, males, and females $\times$ males, respectively. $\theta_{\mathrm{p}}^{2}$ is the phenotypic variance for females, males, or females $\times$ males, as appropriate.

ment of IVDMD, a trait with high GCA effects that had significant differences among hybrids averaged over both males and females and no significant interactions with years. Higher IVDMD was explainable, at least in part, by lower values for NDF, ADF, and ADL, but in this study statistical analyses failed to provide any justification for using the latter traits in a practical breeding program. However, in maize, genetic differences in IVDMD were highly correlated to stover NDF (6). Burton (2), working with bermudagrass [Cynodon dactylon (L.) Pers.], reported gains in IVDMD by breeding and found that animal gains in pasture trials exceeded the percentage increase in IVDMD. As this example so clearly shows, putative improvement in forage quality based on laboratory procedures must be verified (or refuted) by actual measurements of animal performance.

\section{REFERENCES}

1. Blum, A. 1968. Estimates of general and specific combining ability for forage yield in $F_{1}$ hybrids of forage sorghum. Crop Sci. 8:393394.

2. Burton, G. W. 1973. Breeding better forages to help feed man and preserve and enhance the environment. BioScience 23:705-710

3. Dangi, O.P., and R. S. Paroda. 1978. Combining ability analysis for yield and its components in forage sorghum. Indian J. Agric. Sci. 48:287-290.
4. ----, and ----. 1978. Combining ability for quality characters in forage sorghum. Z. Pflanzenzuchtung 80:38-43.

5. Danley, M. M., and R. L. Vetter. 1973. Changes in carbohydrate and nitrogen fractions and digestibility of forages: Maturity and ensiling. J. Anim. Sci. 37:994-999.

6. Deinum. B., and J. J. Bakker. 1981. Genetic differences in digestibility of forage maize hybrids. Neth. J. Agric. Sci. 29:93-98.

7. Goering, H. K., and P. J. Van Soest. 1970. Forage fiber analyses. USDA Agric. Handb. No. 379.

8. Grewal, R. P. S., and R. S. Paroda. 1974. Heterosis and combining ability in forage sorghum. Maydica 19:107-119.

9. Gupta, S. C., R. L. Paliwal, and J. S. Nanda. 1976. Combining ability for forage yield and quality characters in sorghum [Sorghum bicolor (L.) Moench]. Egyptian J. Genet. Cytology 5:89-97.

10. Horwitz, W. 1960 . Association of Official Agricultural Chemists. Official methods of analyses of the A. O. A. C. (9th ed.), A. O. A. C., Washington, D. C

11. McCullough, M. E., and D. G. Cummins. 1974. Factors involved in sorghum silage quality. Georgia Agric. Res. 15:8-10.

12. Owen, F. G., and W. J. Moline. 1970. Sorghum for forage. p. 382415. In J. S. Wall and W. M. Ross (ed.). Sorghum production and utilization. AVI Publ. Co., Inc., Westport, Conn.

13. Robertson, J. B., and P. J. Van Soest. 1977. Dietary fiber estimation in concentrate feedstuffs. p. 254. In Am. Soc. Anim. Sci. Abstracts 69th Annu. Meeting, Univ. of Wisconsin, Madison, Wis

14. Ross, W. M., H. J. Gorz, F. A. Haskins, and K. D. Kofoid. 1979 Combining ability in forage sorghum hybrids. Maydica 24:83-93

15. Schmid, A. R., R. D. Goodrich, R. M. Jordan, G. C. Marten, and J. C. Meiske. 1976. Relationships among agronomic characteristics of corn and sorghum cultivars and silage quality. Agron. J. 68:403406.

16. Snedecor, G. W., and W. C. Cochran. 1967. Statistical methods, sixth edition. Iowa State Univ. Press, Ames, Iowa.

17. Tarumoto, Isao. 1971. Studies on breeding forage sorghums by utilizing heterosis. Bull. Chugoku Natl. Agric. Exp. Stn., Series A, No. 19.

18. Tilley, J. M. A., and R. A. Terry. 1963. A two-stage technique for the in vitro digestion of forage crops. J. Br. Grassl. Soc. 18:104-111.

19. U. S. Department of Agriculture. 1980. Agricultural Statistics, USDA. U. S. Government Printing Office, Washington, D. C.

20. Van Soest, P. J. 1965. Symposium on factors influencing the voluntary intake of herbage by ruminants: Voluntary intake in relation to chemical composition and digestibility. J. Anim. Sci. 24:834-843.

21. -..- 1975. Physico-chemical aspects of fibre digestion. p. 351-364. In Proc. IV Int. Ruminant Cong., Sydney, Australia.

22. ----, and D. R. Mertens. 1977. Analytical parameters as guides to forage quality. p. 50-52. In Proc. Int. Meeting on Anim. Prod. from Temp. Grassl., Dublin, Ireland.

23. ----, and L. A. Moore. 1965. New chemical methods for analysis of forages for the purpose of predicting nutritive value. p. 783-789. In Proc. 9th Int. Grassld. Congr. São Paulo, Brasil.

24. Ward, G. M., F. W. Boren, E. F. Smith, and J. R. Brethour 1966. Relation between dry matter content and dry matter consumption of sorghum silage. J. Dairy Sci. 49:399-402. 